\title{
Seasonal Changes in Thermoregulation and Maximum Metabolism in the Yellow-necked Field Mouse ${ }^{1}$
}

\section{Teresa CYGAN}

\begin{abstract}
Cygan T., 1985: Seasonal changes in thermoregulation and maximum metabolism in the yellow-necked field mouse. Acta theriol., 30, 4: 115-130 [With 1 Table \& 4 Figs.]

Seasonal changes in thermoregulation efficiency and basal metabolism rate (BMR) were studied in Apodemus flavicollis (Melchior, 1834). The animals had significantly greater body weight in winter than in summer and the body weight of females differed significantly from that of males. The average rectal temperature in winter was $37.0 \pm 1.6{ }^{\circ} \mathrm{C}$. There were two cases of spontaneous decrease in rectal temperature to 31.5 and $34.2{ }^{\circ} \mathrm{C}$. During the experiments carried out in helium-oxygen mixture, a decrease in body temperature to as much as 15 and $12{ }^{\circ} \mathrm{C}$ was noted, without lethal effect. The maximum thermogenesis values extrapolated to $-20{ }^{\circ} \mathrm{C}$ in summer reached $11.6 \pm 0.8 \mathrm{~cm} \mathrm{O} \times \mathrm{g}^{-1} \times \mathrm{hr}^{-1}$ and extrapolated to $-30^{\circ} \mathrm{C}$ in winter reached $13.4 \pm 1.6 \mathrm{~cm} \mathrm{O} \times \mathrm{gg}^{-1} \times \mathrm{hr}^{-1}$. BMR in summer $\left(2.9 \pm 0.3 \mathrm{ccm} \mathrm{O}_{2} \times \mathrm{g}^{-1} \times \mathrm{hr}^{-1}\right)$ did not differ significantly from that determined in winter $(3.0 \pm 0.4 \mathrm{ccm}$ $\mathrm{O}_{2} \times \mathrm{g}^{-1} \times \mathrm{hr}^{-1}$ ). In summer, themaximum metabolism was four times higher, and in winter four and half times higher that the BMR.

[Department of Animal Ecology, Jagiellonian University, Karasia 6, 30-060 Kraków, Poland].
\end{abstract}

\section{INTRODUCTION}

Snall mammals can compensate the seasonal increase in energy expenditure caused by low air temperatures and shortage of food by a range of physiological adaptations. In many mammals, the ability to maintain high heat production during long periods of time may decide on the very survival. Acclimatization-related changes in quantity of heat that can be generated in the body of an animal have been studied by Roseumann et al. (1975), Scelza \& Knoll (1979), Feist \& Morrison (1980), Wickler (1980). The maximum heat production may be achieved during physcal effort (Bedford et al., 1979), shivering or non-shivering thermo-

1 Badania prowadzono $w$ ramach problemu MR.II.15 koordynowanego przez Instytat Ekologii PAN. 
genesis (Rosenmann \& Morrison, 1974, Pasquis et al., 1970). Seasonal alterations in the thermogenic capacity may be stimulated by changes in ambient temperature, trophic conditions of photoperiod (Steinlechner \& Heldmaier, 1981; Heldmaier et al., 1982). The metabolic capacity may in turn be limited by performance of respiratory and cardiovascular systems (Lechner, 1978; Pasquis et. al., 1970), rate of supplying substrates for thermogenesis (Wang, 1978, 1980) and finally, the performance of enzymatic systems at the cell level (Wickler, 1981).

The aim of this work was to follow acclimatization-induced changes in thermoregulation, maximum thermogenesis and basal metabolism rate in Apodemus flavicollis. The aerobic metabolism and thermoregulation of this species have already been studied by Kalabukhov $(1951,1969)$ and Gębczyński (1966). Yet the maximum metabolism has not been included in these studies and the relevant thermoregulation curves presented in from that preclude coming to any definite conclusions about the thermoregulation strategy in this species.

\section{MATERIAL AND METHOD}

The yellow-necked mice Apodemus flavicollis (Melchior, 1834) were caught in Niepołomice Forest near Cracov $\left(20^{\circ} 15^{\prime} \mathrm{E}, 50^{\circ} 5, \mathrm{~N}\right)$ during spring and autumn 1983. The animals were kept in separate cages in summer and in pairs of the same sex during winter. Nest material put in cages included hay and sawdust with cotton wool and pieces of wadding added in winter. The animals were to be acclimatized to natural temperature and photoperiod changes, hence the cages were placed outdoors under shelter. The food given included wheat and barley grain, apples, beets, cottage cheese, and water provided ad libitum. In summer the experiments were carried out on 24 , and in winter on 22 animals of both sexes. All the mice used in summer were caught in the field prior to experiments; some of the animals were kept outdoors for winter series of experiments.

The metabolism rates were measured as oxygen consumption in closed-system Kalabukhov-Skvortsov respirometer (Górecki, 1975) in metabolic chamber of 0.5 litre capacity. Initial part of the experiment was carried out in normal atmosphere that initially filled the chamber, and lasted about 70 minutes. Next, 10 litres of helium-oxygen mixture $(79 \% \mathrm{He}, 21 \% \mathrm{O})$ were blown rapidly through the chamber replacing the air in it. The chamber was then sealed again and the oxygen consumption measured. The thermal conductivity of helium is about six times higher than that of nitrogen (Rosenmann \& Morrison, 1974). Thus the helium-oxygen mixture helped to simulate temperature condition much below $0{ }^{\circ} \mathrm{C}$ and hence incurring corresponding huge heat loss that made possible measuring the maximum thermogenesis (Wickler, 1980; Abbotts \& Wang, 1980). The measurements in the helium-oxygen mixture lasted not less than 15 minutes but never exceeded 70 minutes. First ten minutes of each run were not taken into consideration because in this time the temperature inside the chamber levelled with that of bath, and the animals had a time to adjust to experimental conditions. The oxygen consumption was monitored in 5-minute intervals. In order to obtain the metabolism rate in a given temperature, a mean has been calculated from all the measurements 
of oxygen consumption taken. The highest values of oxygen consumption obtained in helium-oxygen mixture at low temperatures were used for obtaining the values of maximum thermogenesis calculated as a mean from series of high values. When the animals did not maintain the high initial level of metabolism but lowered it drastically, such results were not taken into account. The immediate drop in metabolism manifested inability of an animal to cope with thermal conditions and subsequently entering a hypothermy. When the amount of oxygen consumed wais very small or dropped rapidly the experiment was ended immeciately. In winter the experiments were supplemeted by a series of shortlasting measurements in helium-oxygen mixture only, of establish if the maximum metabolism was in any way affected by fact that the animals were kept in chambers without food (Wang, 1980).

The basal metabolism rates (BMR) were determined in mice that fasted for 5 hours before the experiment. The ambient temperature was $30{ }^{\circ} \mathrm{C}$ and the experiments lasted $30-60$ minutes.

The first series of experiments on thermoregulation was carried out in summer (July) at temperatures ranging from 4.5 to $25.5{ }^{\circ} \mathrm{C}$, the second series in winter (February and early March) at temperatures from -5 to $+20{ }^{\circ} \mathrm{C}$.

In winter, before and after the experiments, the rectal temperature, to the nearest $0.1{ }^{\circ} \mathrm{C}$, was taken with a thermistor probe.

All the animals had been weighed (to the nearest $0.1 \mathrm{~g}$ ) before the experiment started.

The activity of A. flavicollis changes with time of day and season (Gebczyński, 1960; it was thus decided to carry out all the experiments at the fixed time of day (from 3 to 8 p.m.).

All results are given as means with standard deviation ( $\overline{\mathrm{X}} \pm \mathrm{SD})$.

Student's test was used to asses the statistical significance of differences betveen means while the analysis of covariance (Zar, 1974) served for estimation of the significance of differences between regression coefficient (slope, elevation). Anc finally the multiple regression and Mann-Whitney's nonparametric test was used for comparing the maximum metabolism rates in animals of various sex and body weight.

\section{RESULTS}

\section{Seasonal Changes in Body Weight}

The mean body weight of animals used in summer experiments was $25.1 \pm 7.0 \mathrm{~g}(\mathrm{~N}=24)$. Body weight of females ranged from 18 to $32 \mathrm{~g}$ (man $22.6 \pm 4.2 \mathrm{~g}, \mathrm{~N}=12$ ) and that of males from 16 to $43 \mathrm{~g}$ (meant 29.. $\pm 8.2 \mathrm{~g}, \mathrm{~N}=12$ ).

In winter the body weight of mice was $31.1 \pm 5.7 \mathrm{~g}$ on average $(\mathrm{N}=22)$. Fenales weighed from 25 to $31 \mathrm{~g}$ (mean $27.4 \pm 2.3 \mathrm{~g}, \mathrm{~N}=10$ ), males from 25 o $45 \mathrm{~g}$ (mean $34.2 \pm 5.8 \mathrm{~g}, \mathrm{~N}=12$ ).

The differences in body weight between sexes were statistically significart $(p<0.05)$. Also the overall mean weight determined in summer difered significantly from those in winter $(p<0.05)$. 


\section{Body Temperature in Winter}

The average rectal temperature before experiment was $37.2 \pm 1.6{ }^{\circ} \mathrm{C}$ $(\mathrm{N}=45)$. In two animals the temperatures were particularly low at 31.5 and $34.2{ }^{\circ} \mathrm{C}$. The highest rectal temperature noted was $40.8^{\circ} \mathrm{C}$.

During the experiment some changes in body temperature occurred (Fig. 1). Within the range of temperatures from 10 to $20{ }^{\circ} \mathrm{C}$ applied in experiment the rectal temperature dropped by 0.2 to $6.4{ }^{\circ} \mathrm{C}$, only in one case rising by $0.2{ }^{\circ} \mathrm{C}$. At lower temperatures the changes in body temperature ranged from 4.7 to $24{ }^{\circ} \mathrm{C}$. When in hypothermy, the animals were less active and shivered markedly. After the animals had been warmed up in the stream of warm air they returned to initial condition.

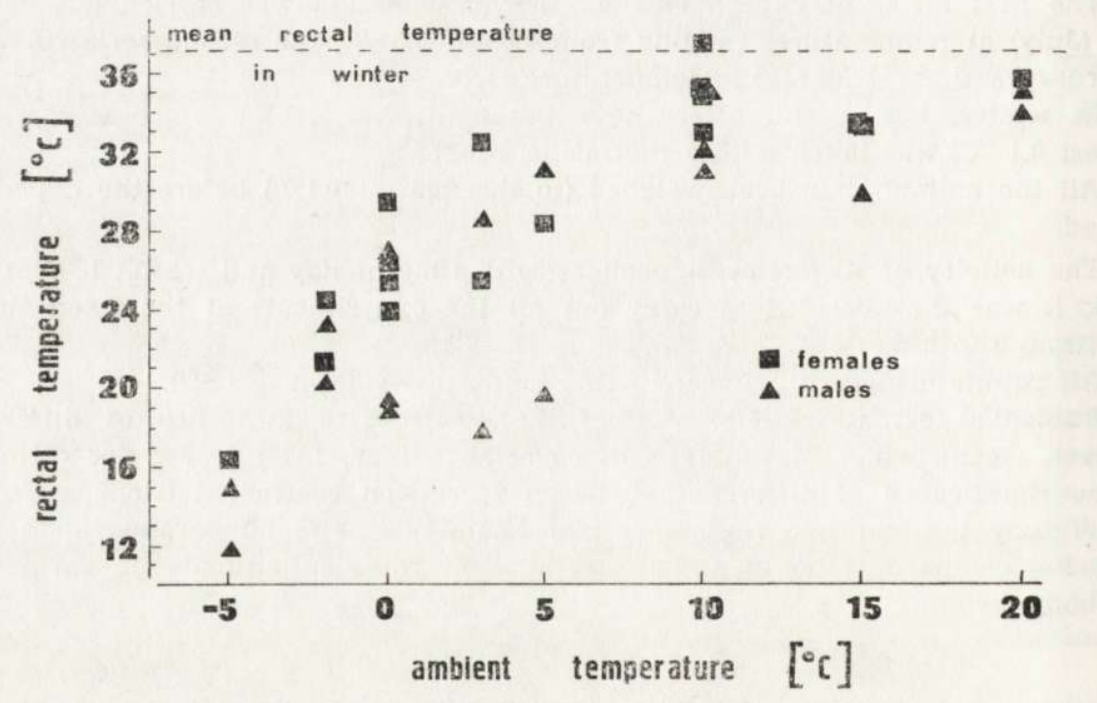

Fig. 1. Effect of the ambient temperature on the rectal temperature of Apodemus flavicollis. Measurements taken after measurements of metabolism.

\section{Basal Metabolism}

The basal metabolism rate did not differ significantly in both seasons: in summer it was $2.9 \pm 0.3 \mathrm{ccm} \mathrm{O} \times \mathrm{g}^{-1} \times \mathrm{hr}^{-1}$ on average $(\mathrm{N}=7)$, while in winter the mean value was quite similar at $3.0 \pm 0.4 \mathrm{ccm} \mathrm{O} \times \mathrm{g}^{-1} \times \mathrm{hr}^{-1}$ $(\mathrm{N}=7)$.

\section{Thermoregulation in Normal Atmosphere}

The relation between metabolism and ambient temperature for animals of various sex has been described by linear regression equations in the following form: 


$$
M=a+b T a
$$

where $M-$ metabolism rate $\left(\mathrm{ccm} \mathrm{O}_{2} \times \mathrm{g}^{-1} \times \mathrm{hr}^{-1}\right)$,

$\mathrm{T}_{a}$ - ambient temperature $\left({ }^{\circ} \mathrm{C}\right)$.

Regression coefficients $a$ and $b$ together with standard errors so and coefficients of determination $r^{2}$ for males and females in two seasons are given in Table 1. The thermoregulation curve found for mice of both sexes in summer in the range of ambients from 4.5 to $25.5^{\circ} \mathrm{C}$ is described by regression (1) (Table 1, Fig. 2A). The values of metabolism attained

Table 1

Parameters of equations of regression $(M=a+b T a)$ of metabolism (M, ccm $\left.\mathrm{O}_{2} \times \mathrm{g}^{-1} \times \mathrm{hr}^{-1}\right)$ to ambient temperature $\mathrm{Ta}\left({ }^{\circ} \mathrm{C}\right)$ in Apodemus flavicollis.

\begin{tabular}{lcccccc}
\hline Season, & Intercept & $\begin{array}{c}\text { Regression } \\
\text { coeff. } \\
\text { sex }\end{array}$ & $\begin{array}{c}\text { SE of } \\
\text { regression } \\
\text { coeff. } \\
\text { sb }\end{array}$ & $\begin{array}{c}\text { Coeff. of } \\
\text { deter- } \\
\text { mination } \\
r^{2}\end{array}$ & $\begin{array}{c}\text { Sample } \\
\text { size } \\
n\end{array}$ & $\begin{array}{c}\text { No. of the } \\
\text { equation }\end{array}$ \\
\hline
\end{tabular}

In the air

Summer

\begin{tabular}{lllllll} 
Pooled & 7.9 & -0.18 & 0.013 & 0.73 & 74 & 1 \\
Females & 8.2 & -0.185 & 0.017 & 0.76 & 37 & 2 \\
Males & 7.3 & -0.17 & 0.015 & 0.78 & 37 & 3 \\
Winter & & & & & & \\
Pooled & 7.9 & -0.19 & 0.012 & 0.85 & 46 & 4 \\
Females & 8.2 & -0.19 & 0.013 & 0.90 & 25 & 5 \\
Males & 7.5 & -0.19 & 0.014 & 0.91 & 21 & 6 \\
\hline
\end{tabular}

In the helium-oxygen mixture

\begin{tabular}{lllllll} 
Summer & & & & & \\
Pooled & 12.0 & -0.23 & 0.030 & 0.60 & 40 & 7 \\
Females & 13.9 & -0.36 & 0.049 & 0.75 & 15 & 8 \\
Males & 11.8 & -0.23 & 0.033 & 0.68 & 25 & 9 \\
Winter & & & & & & \\
Pooled & 15.7 & -0.41 & 0.035 & 0.89 & 20 & 10 \\
Females & 15.8 & -0.41 & 0.042 & 0.91 & 12 & 11 \\
Males & 15.3 & -0.41 & 0.054 & 0.91 & 8 & 12 \\
\hline
\end{tabular}

by females (in summer season) were often higher than corresponding values for males. There were no significant differences between the slope coefficients for both lines (Fig. 3A), but the regression (2) and (3) differ significantly in elevation $(p<0.05)$ (Table 1$)$.

The rates of metabolism obtained within the range of temperatures from -5 to $+20{ }^{\circ} \mathrm{C}$ in winter, are shown on Fig. $2 \mathrm{~B}$ and $3 \mathrm{~B}$. The regression equations for the two sexes differ in elevation $(p<0.05)$. There are no significant statistical differences between the regressions calculated 
for animals of both sexes treated together in summer (Table 1, equation 1) and winter (Table 1, equation 4 ) experiments.

In both seasons, in experiments conducted in normal air the animals
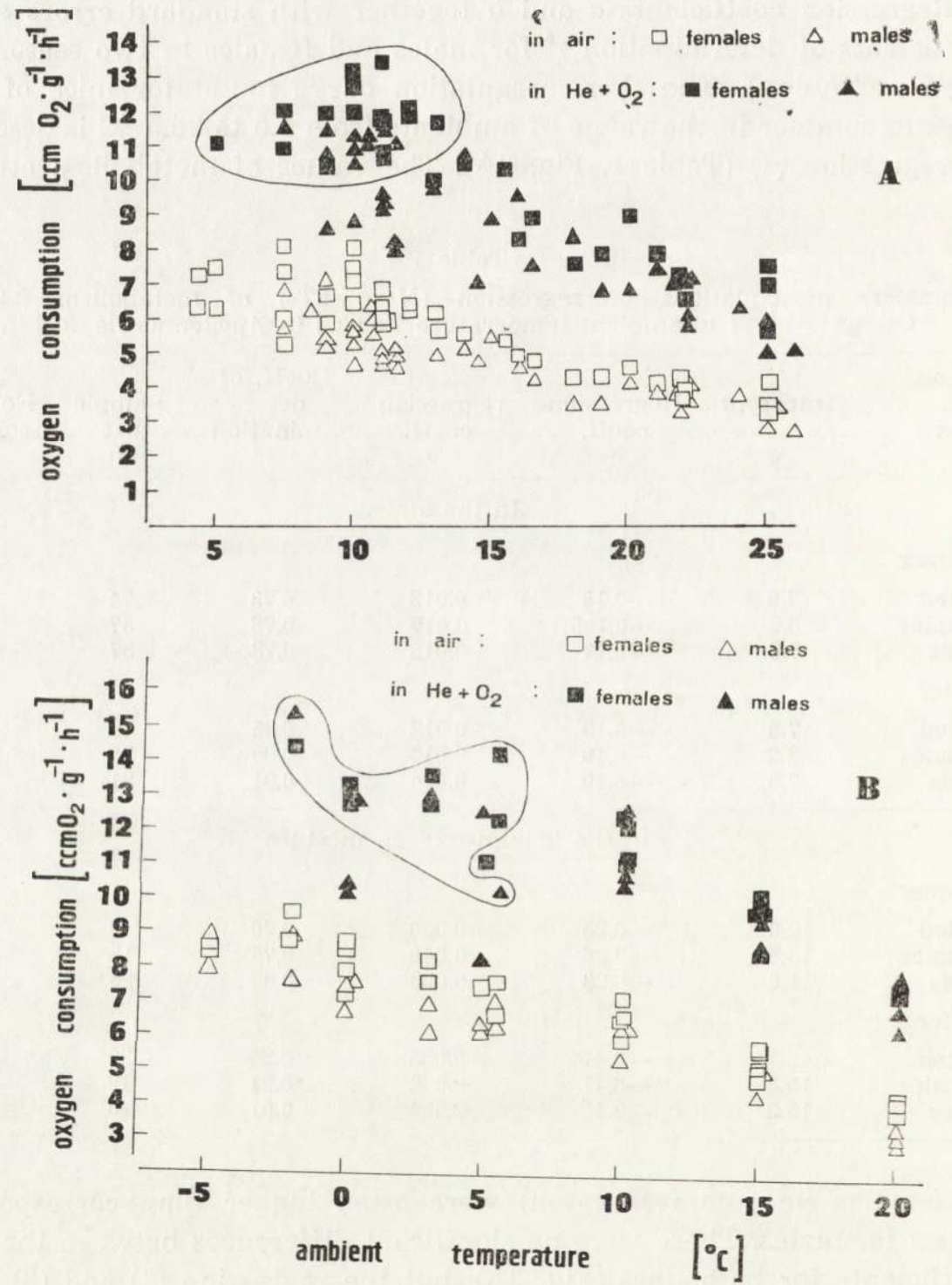

Fig. 2. Relationship between ambient temperature and metabolism in A. flavicollis, measured in air (open symbols) and in helium-oxygen mixture (filled symbols). Crossed symbols indicate values excluded from further calculations (see text for explanation). Encircled symbols results assumed to represent maximum values of metabolism. A - summer; B - winter. 
did not attain the maximum level of metabolism. The oxygen consumption throughout the experiment remained uniform with deviations not exceeding $2-3 \mathrm{ccm} \mathrm{O}_{2}$ per 5 -minute period.

\section{Thermorezulation in Helium-oxygen Mixture and the Rate of Maximum Metabolism}

Some of the results obtained in summer were intended for estimation of the maximum metabolism (Fig. 2A). The remaining results were used for calculating the regression of metabolism in relation to the ambient temperatures of 9 to $25.5{ }^{\circ} \mathrm{C}$ range (Fig. 3A, Table 1, equation 7).

Similarly to the measurements taken in normal atmosphere, the rates of oxygen consumption by females were higher than corresponding values for males (Table 1, equation 8 and 9). Covariance analysis revealed significant difference between elevations of the regressions for two sexes $(p<0.05)$ with no significant differences in slope.

At ambients ranging from 9 to $25.5{ }^{\circ} \mathrm{C}$ the rate of oxygen consumption was the same at the beginning as the end of experiment. Below this range, at temperatures ranging from 4.5 to $8.5{ }^{\circ} \mathrm{C}$ the amount of oxygen consumed decreased gradually shortly after the experiment had started. In seven mice such drop occurred immediately after the beginning of experiment. The results obtained in these runs were not considered in further calculations.

Three mice attained the higest values of metabolism at 12 and $13{ }^{\circ} \mathrm{C}$ but most did it in the range of temperatures from 9 to $11^{\circ} \mathrm{C}$ (Fig. 2A). In summer the maximum metabolism $\left(M_{\max }\right)$ in the temperature range from 5 to $13{ }^{\circ} \mathrm{C}$ was $11.6 \pm 0.8 \mathrm{ccm} \mathrm{O}_{2} \times \mathrm{g}^{-1} \times \mathrm{hr}^{-1}$ on average $(\mathrm{N}=27)$ with its highest value at $13.4 \mathrm{ccm} \mathrm{O}_{2} \times \mathrm{g}^{-1} \times \mathrm{hr}^{-1}$. In females the maximum metabolism was $11.8 \pm 0.9(\mathrm{~N}=17)$ in males $11.4 \pm 0.3 \mathrm{ccm} \mathrm{O} \times \mathrm{Og}^{-1} \times \mathrm{hr}^{-1}$ $(\mathrm{N}=10)$ on average. To test the hypothesis of effect of sex on metabolism, with both differences in body weight and temperature eliminated, a multiple regression was calculated from the maximum values:

$$
M_{\max }=14.53+0.01 T_{a}-0.13 \mathrm{~W} ; R^{2}=0.44 ; \mathrm{N}=27
$$

where $M_{\max }$ - maximum metabolism rate in $\mathrm{ccm} \mathrm{O}_{2} \times \mathrm{g}^{-1} \times \mathrm{hr}^{-1}$,

$\mathrm{T}_{a}$ - ambient temperature in ${ }^{\circ} \mathrm{C}$,

$W-$ body weight in $\mathrm{g}$.

Coefficients of partial correlation $r_{m t} \cdot w=0.03$ and $r_{m w} \cdot t=-0.65$ indicate a neglible effect of body weight on the maximum metabolism. The deviations of experimential values from the expected ones in equation (I) were not correlated significantly with sex (Mann-Whitney's test, $p<0.05)$.

The changes in thermoregulation in winter are shown in Fig. 2B. 
Only the experiments during which mice consumed oxygen more or less evenly throughout the run, and had the rectal temperature above $30{ }^{\circ} \mathrm{C}$, were taken into consideration. Two regression lines obtained for females
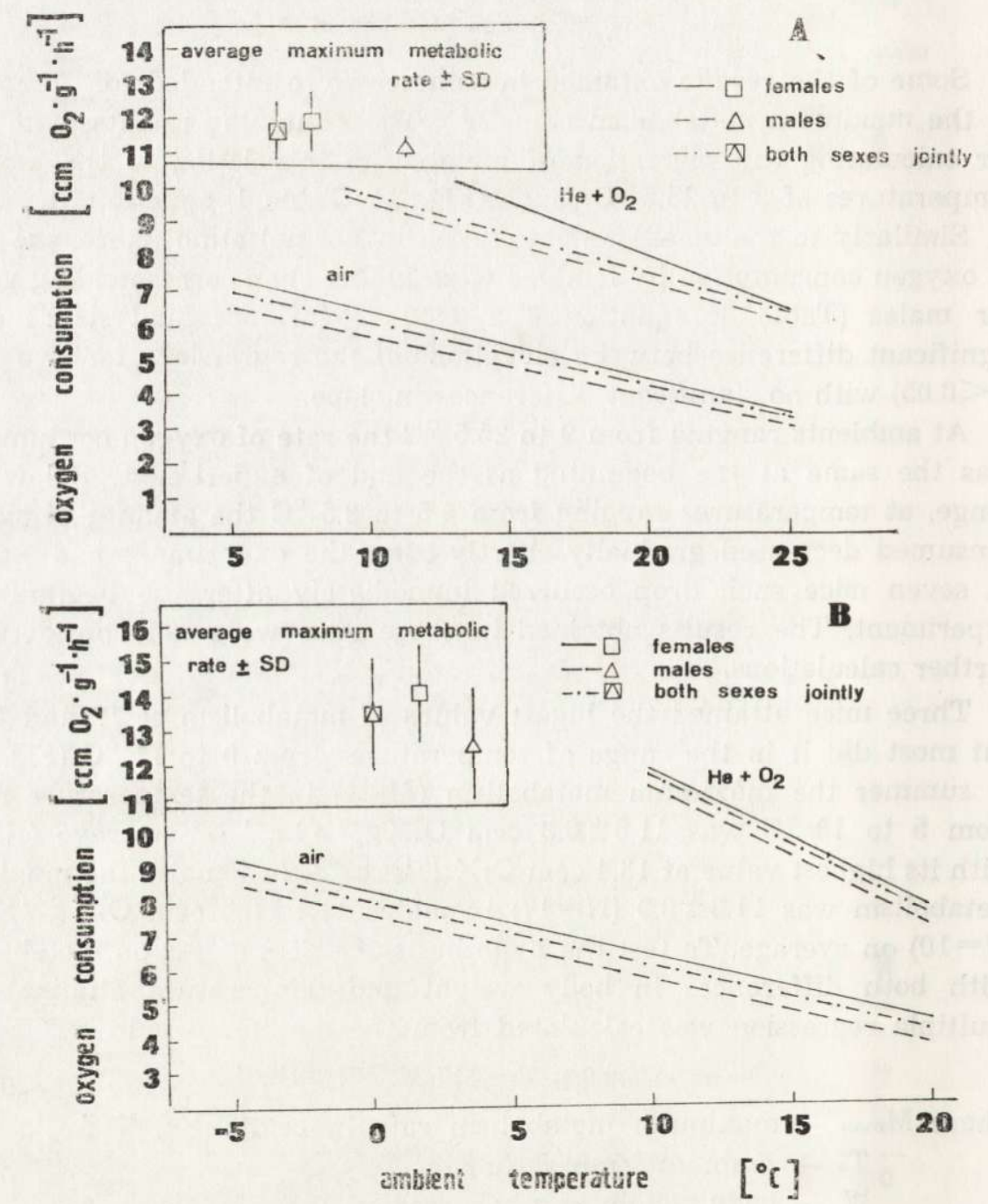

Fig. 3. Themoregulation curves and maximum metabolism values in A. flavicollis of both sexes, in air and in helium-oxygen mixture. A - summer; B - winter.

(equation 11) and males (equation 12) in the temperature range from 10 to $20{ }^{\circ} \mathrm{C}$ did not differ significantly (Table 1, Fig. 3B).

The highest values of the maximum metabolism were noted in the 
range of temperatures from -2 to $+5.5{ }^{\circ} \mathrm{C}$. At $-5{ }^{\circ} \mathrm{C}$ the animals were unable to maintain a high metabolism rate, reduced their oxygen consumption and lowered body temperature (in one case drop in rectal temperature of as much as $24{ }^{\circ} \mathrm{C}$ was noted) and hence the results could not be included in calculations. Similarly, the results obtained at 0 and $+5{ }^{\circ} \mathrm{C}$ were not included in calculations, because the animals used here demonstrated a higher metabolism rates during experiments conducted

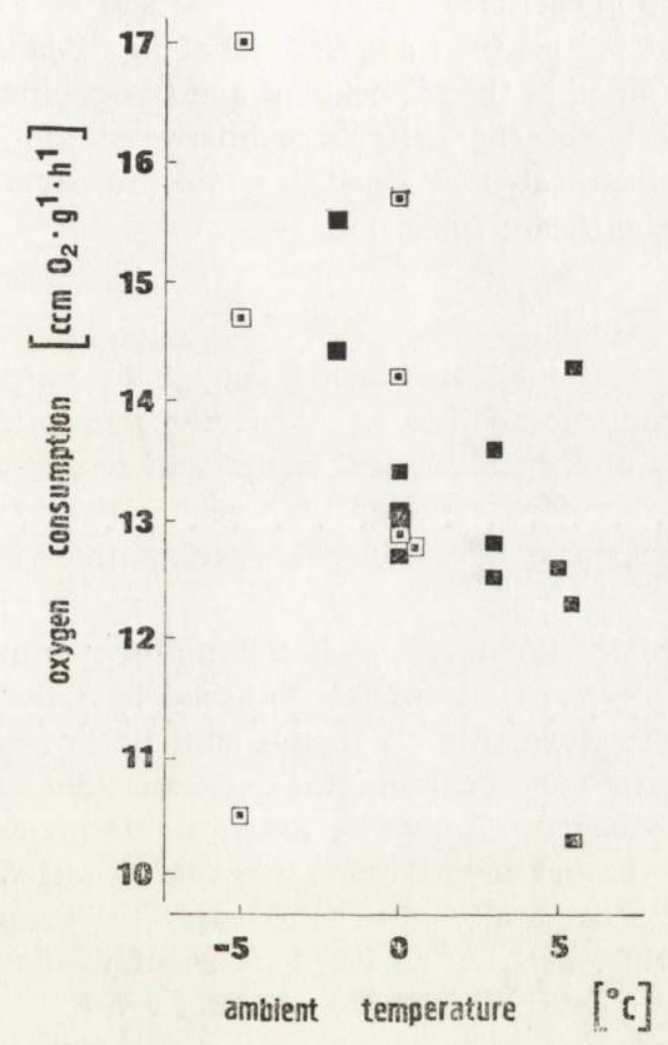

Fig. 4. Relationship between rate of metabolism and ambient temperature in measurement of various duration. Open symbols: short measurements in heliumoxygen mixture only; filled symbols: measurements in air followed by runs in helium-oxygen mixture.

at other temperatures. The average of the maximum metabolism rate (in temperatures from -2 to $+5.5{ }^{\circ} \mathrm{C}$ ) was $13.2 \pm 1.1 \mathrm{ccm} \mathrm{O}_{2} \times \mathrm{g}^{-1} \times \mathrm{hr}^{-1}$ $(\mathrm{N}=13)$ with the highest value of $15.5 \mathrm{~cm} \mathrm{O} \times \mathrm{g}^{-1} \times \mathrm{hr}^{-1}$.

In the shorter experiments carried out only in helium-oxygen atmosphere at 0 and $-5{ }^{\circ} \mathrm{C}$ the average value of maximum metabolism was $14.0 \pm 2.1 \mathrm{~cm} \mathrm{O} \times \mathrm{g}^{-1} \times \mathrm{hr}^{-1}(\mathrm{~N}=7)$ with the highest value at $17.0 \mathrm{ccm}$ 
$\mathrm{O}_{2} \times \mathrm{g}^{-1} \times \mathrm{hr}^{-1}$ (Fig. 4). The mean did not differ significantly $(p<0.05)$ from that obtained in previous series. This fact justified subsequent pooling of the results obtained in these two series. The average values thus calculated were $13.4 \pm 1.6 \mathrm{~cm} \mathrm{O} \times \mathrm{g}^{-1} \times \mathrm{hr}^{-1}$ for all animals $(\mathrm{N}=20)$, $14.0 \pm 1.4$ and $12.5 \pm 1.6 \mathrm{ccm} \mathrm{O} \times \mathrm{g}^{-1} \times \mathrm{hr}^{-1}$ for females $(\mathrm{N}=12)$ and males $(\mathrm{N}=8)$ respectively. A multiple regression was then calculated:

$$
M_{\max }=19.48-0.19 T_{c}-0.20 \mathrm{~W} ; R^{2}=0.58 ; \mathrm{N}=20
$$

and partial correlation coeficients $r_{m t} \cdot w=-0.52$ and $r_{m w} \cdot t=-0.70$. Mann-Whitney's test did not confirm any statistical significance of differences between values obtained in the experiment and those expected by equation (II) for both sexes. Yet the differences between the mean values of maximum metabolism rates attained by mice in summer and winter were statistically significant $(p<0.05)$.

\section{DISCUSSION}

In this paper an attempt has been made to investigate the seasonal changes in maximum metabolism in Apodemus flavicollis. Animals have been kept outdoors under the natural regimes of temperature and photoperiod. It may be therefore assumed than acclimatization-related physiological changes that have taken place resemble those occurring in the wild.

At low ambients, the animals kept in helium-oxygen mixture displayed on initial peak in oxygen consumption followed by later by a decrease a drop in body temperature (Fig. 1). Some animals lowered their oxygen consumption from the very beginning of the experiment and immediately entered deep hypothermy. However, even the large decrease in body temperature, up to several centigrades was not lethal. When transferred to higher ambients the mice intensified the shivering thermogenesis (single initial convulsions later replaced by regular shivers) thus helping the body temperature return quickly to normal level.

The rectal temperatures were measured only in winter. A spontaneous drop in this temperature (not induced by experimental conditions) was observed twice. It fell remarkably below average, reaching 31.5 and $34.2{ }^{\circ} \mathrm{C}$. Such spontaneous reduction of the body temperature and enduring hypothermy may suggest capability of the yellow-necked mice to enter short spells of torpor. In closely related species of wood mouse. Apodemus sylvaticus (Linnaeus, 1758), such phenomenon was first observed in field by Morris (1968). While Walton \& Andrews (1981) observed in the same species a torpor induced by fast and exposure to low temperatures (simultaneous drop in oxygen consumption, body temperature to below $31{ }^{\circ} \mathrm{C}$ ). Similar phenomena have been described in other small 
rodent species. Mus musculus (Linnaeus, 1758) may enter short spells of torpor under conditions of thermal comfort and adequate food supply, but does it more often as a reaction to starving (Hudson \& Scott, 1979). In Peromyscus leucopus (Rafinesque, 1818) the spontaneous daily torpor occurs at low temperatures in winter months, even with overabundance of food present, provided that the animals have undergone a prior acclimatization to low temperatures (Gaertner et al., 1973). In Phodopus sungorus (Pallas, 1773) the ability to enter torpor develops under influence of seasonal changes in photoperiod (Heldmaier \& Steinlechner, 1981). The observation of spontaneous decrease of body temperature in A. flavicollis reported in this paper are not too numerous, a fact that may be contributed to the choice of timing of the measurements. In small mammals of nocturnal type of activity short daily torpor comes often during late morning hours (Heldmaier \& Steinlechner, 1981, Walton \& Andrews, 1981).

There was a marked sexual dimorphism in body size among animals used in the experiments. In winter the experimental animals were heavier than those used in summer. Gębczyński (1966) reported similar differences but the animals he studied had been captured further north at Białowieża $\left(23^{\circ} 50^{\prime} \mathrm{E}, 52^{\circ} 40^{\prime} \mathrm{N}\right)$ and were, in both seasons, slightly larger than mice from Niepolomice Forest used in this work.

The curves representing the thermoregulation in air for A. flavicollis in summer and winter do not differ in slope, and there is not much difference in the corresponding values of oxygen consumption either. This provides ground for assumption that there is no difference in the overall heat conductance. These findings somehow contradict those of Kalabukhov (195., 1969) and Gębczyński (1966) who found higher values of metabolism and steeper line representing the relation between metabolism and ambent temperature in summer than that in winter. Yet these works do rot include respective regression equations and standard deviations lack of which precludes making any estimation of statistical significance of differences.

The basal metabolism rate in A. flavicollis has not changed following seascnal acclimatization (2.9 and $3.0 \mathrm{ccm} \mathrm{O}_{2} \times \mathrm{g}^{-1} \times \mathrm{hr}^{-1}$ in summer and winter respectively). These values are similar to those obtained for other species of Muridae of similar size by Grodziński \& Wunder (1975).

On the other hand the maximum oxygen metabolism that represents a miximum production of heat, was higher by 16 per cent in winter. There was also a seasonal shift in temperature at which the animals attained the maximum thermogenic capacity $\left(10{ }^{\circ} \mathrm{C}\right.$ in summer, $5{ }^{\circ} \mathrm{C}$ in winter) in oxygen-helium mixture. By extrapolation of the thermoreguation curves (equations 7 and 10) to the values of maximum 
metabolism for summer and winter, respective critical temperatures of $-20{ }^{\circ} \mathrm{C}$ and $-30{ }^{\circ} \mathrm{C}$ were obtained. Hence if BMR stabilizes at certain level and the value of maximum metabolism alters, this imply a seasonal changes in ability to increase the metabolism rate (broadening a metabolic scope). In summer a yellow-necked field mouse can increase its oxygen consumption up to four times while in winter that factor rises to. 4.5. The maximum metabolism (maximum thermogenesis) has been determined in may species of rodents (Rosenmann \& Morrison, 1974, Rosenmann et al., 1975, Feist \& Morrison, 1981). The rate of it changes allometrically with body weight (Pasquis et al., 1970, Weiner, unpubl. data) and undergoes seasonal acclimatization though it usually falls into the range between three times and eight times the BMR value (Pasquis et al., 1970, Rosenmann \& Morrison, 1974, Rosenmann et al., 1975, Abbotts \& Wang, 1980). The maximum metabolism in A. flavicollis do fall within this range. The acclimatization strategy in small homoiothermic animals is realized by careful modifications of their energy balance to adjust it to changing environmental predicament. The climatic changes, having disturbed a heat balance, may, on the other hand, bring about alternations in food supply. The seasonal acclimatization related to the energy balance may include changes in the body weight, insulation of pelage, basal metabolism rate, and maximal thermogenesis, and finally may include an ability to enter short or long-lasting torpor (hibernation). In various species the physiological acclimatization is realized by diverse combinations of these mechanisms.

The data obtained in this study indicate that, in both seasons, A. flavicollis has similar basal metabolism rate and overall thermoconductance. A response to the elevation of energy expenditure in winter is, in this species, realized by an increase in body weight (improving area/volume ratio) and in heat-generation capacity (higher maximum metabolism). Both of these seasonal adaptations lead to increased demand for food which is scarce in winter. In A. flavicollis this is compensated by the ability to enter short daily torpors that may greatly reduce total energy expenditures as has been found in this study. Such conclusions are not supported by the findings reported by Gergilevich \& Smirnov (1970) who studied the seasonal changes in fur insulation in A. flavicollis. In the animals from the continental part of the USSR both length and density of hair was greater in winter than in summer. Sawicka-Kapusta (1968) studied annual cycles of fat and water contents in mice of the same species collected in Cracov region. Distinct annual cycles were found for both these components. The fat content rose in autumn and early winter (up to $20.9 \%$ ) and later declined in spring and summer (to $11.9 \%$ ). Perhaps the seasonal changes in acclimatization occur in animals obtained 
from regions with severe winters, but this is not supported by evidence provided by Sawicka-Kapusta (1968).

A. flavicollis has its North American ecological equivalent in Peromyscus leucopus, whose annual changes of metabolism have been studied by Wickler (1980). P. leucopus maintains unchanged body weight of about $18-19 \mathrm{~g}$, but has, in winter, a maximum metabolism rate of $19.5 \mathrm{ccm}$ $\mathrm{O}_{2} \times \mathrm{g}^{1-} \times \mathrm{hr}^{-1}$, exceeding that in summer by as much as 68 per cent. The thermoconductance in winter is lower by 20 per cent, possibly owing beter insulation of pelage. This species is also known for its ability to enter short daily torpors (Wickler, 1980).

The rodents living in regions with severe climate conditions in winter display still more profoung modifications of metabolism and body weight. Voles of Clethrionomys rutilus dawsoni (Pallas, 1779), the species from Alaska, may reduce its body weight from 28 to $13 \mathrm{~g}$, and increase its $M_{\max }$ from 13.5 to $23.05 \mathrm{ccm} \mathrm{O}_{2} \times \mathrm{g}^{-1} \times \mathrm{hr}^{-1}$ (Rosenmann et al., 1975). In Prodopus sungorus from continental Asia the body weight is greatly reduced in winter, and the disadvantageous area volume ratio compensated by a much better insulation of pelage. In addition the species manifests the ability to increase the maximum thermogenesis and to enter short spells of torpor (Heldmaier et al., 1982, Puchalski et al., 1983). By such strategy, these two species ensure much needed reduction of the overall ener£y requirement in winter.

On the other hand tropical species (e.g. Calomys callosus) (Rosenmann \& Norrison, 1974) (and desert ones (e.g. Dipodomys panamintinus (Merriam, 1894)) (Scelza \& Knoll, 1979) attain lower maximum metabolism and their body weight show an increasing tendency in winter. When compared with the data mentioned above the mice studied in this work apperred to have relatively low level of the physiological adaptation to seasonal changes in environment. This conclusion is also supported by a difference in degree of acclimatization attained by mice captured in Niepołomice Forest and those from Białowieża, situated $400 \mathrm{~km}$ further north (Gębczyński, 1966). It should also be noted that the yellow-necked field mice have developed quite efficient social thermoregulation; in lowe: temperatures they can improve the heat economy by huddling togetier into groups of $4-5$ animals (Fedyk, 1971). It may well be that poor manifestation of the physiological adaptation resulted from the abunlant supply of food and particularly mild condition prevailing during the vinter of experiments. It could provide ground for speculation that in A flavicollis the principal factors governing the effect of acclimatization might be of climatic or trophic nature whereas in $P$. sungorus it 
is the photoperiod which causes distinct acclimatization-related changes (Heldmaier \& Steinlechner, 1981).

There was marked tendency in the females of A. flavicollis to attain higher maximum metabolism values compared with males - an occurrence repeated throughout all the series of the experiments. This effect might have been connected with the differences in body weight (though the statistical analysis provided no definite answer) but might also be of adaptive value. In some seasons the females of $D$. panamintinus also had a higher maximum metabolism per unit of body weight (Scelza \& Knoll, 1979); similar phenomenon have been observed in rats by Bedford et al. (1979) who found that females of the upper age class had higher metabolism than males, irrespective of body weight. Koteja (1984) has lately found similar tendency in the house sparrow. Proving the hypothesis stating that there is a difference between female and male homoiotherms in level of maximum thermogenesis still requires further studies.

Acknowledgements: The author wishes to express his sincere gratitude to J. Weiner Ph. D. for his indispensable help and advice; to Professors W. Grodziński, Z. Pucek, and M. Gębczyński for their remarks on the final version, and finally to R. Tertil Ph. D. for putting the text into English.

\section{REFERENCES}

1. Abbotts B. \& Wang L. C. H., 1980: Seasonal thermogenic capacity in a hibernator, Spermophilus richardsonii. J. Comp. Physiol., 140: 235-240.

2. Bedford T. G., Tipton C .M., Wilson N. C., Oppliger R. A. \& Gisolfi C. V., 1979: Maximum oxygen consumption of rat and its changes with various experimental procedures. J. Appl. Physiol., 47: 1278-1283.

3. Fedyk A., 1971: Social thermoregulation in Apodemus flavicollis (Meichior, 1834). Acta theriol., 16: 221-229.

4. Feist D. D. \& Morrison P. R., 1981: Seasonal changes in metabolic capacity and norepinephrine thermogenesis in the Alascan redbacked vole: Environmental cues and annual differences. Comp. Biochem. Physiol, 69 A: 697-700.

5. Gaertner R. A., Hart J. S. \& Roy O. Z., 1973: Seasonal spontaneous torpor in the white-footed mouse, Peromyscus leucopus. Comp. Biochem. Physiol, 45 A: $169-181$.

6. Gergilevič N. M. \& Smirnov P. K., 1970: Seasonal changes of the hair cover of the yellow-necked field mouse Apodemus flavicollis (Rodentia, Mammalia). S. Biologija, 195: 1443-1445.

7. Gębczyński M., 1966: The daily energy requirement of the yellow-necked field mouse in the different seasons. Acta theriol., 11: 391-398.

8. Górecki A., 1975: Kalabukhov-Skvortsov respirometer and resting metabolic rate measurement. [In: "Methods for ecological bioenergeties". W. Grodziński, R. Z. Klekowski, A. Duncan, eds.]. IBP Handbook No 24: 309-313. Blackwell Sci Publ., Oxford.

9. Grodziński W. \& Wunder B. A., 1975: Ecological energetics of small mammals. [In: "Small mammals: their productivity and population dynamics". F. B. Golley, 
K. Petrusewicz, L. Ryszkowski, eds]. Cambridge Univ. Press: 173-204. Cambridge.

10. Heldmaier G, \& Steinlechner S., 1981: Seasonal pattern and energetics of short daily torpor in the Djungarian hamster, Phodopus sungorus. Oecologia, 48: $265-270$.

11. Heldmaier G., Steinlechner S. \& Rafael J., 1982: Nonshivering thermogenesis and cold resistance during seasonal acclimatization in the Djungarian hamster. J. Comp. Physiol., 149: 1-9.

12. Hudson J. W. \& Scott I. M., 1979: Daily torpor in the laboratory mouse, Mus musculus var. albino. Physiol., Zool., 52: 205-218.

13. Kalabukhov N. I., 1951: Metodika eksperimentalnych issledovanij po ekologi naziemnyh pozvonočnych. Gos. Izd. Sov. Nauka. Moskva.

14. Kalabukhov N. I., 1969: Periodical (seasonal and yearly) changes in the organism of rodents, their causes and consequences. Izd. Nauka. Moskva Leningrad. [In Russian].

15. Koteja P., 1984: Maximum cold-induced oxygen consumption in the house sparrow (Passer domesticus, L.). Msc thesis:

16. Lechner A. J., 1978: The scaling of maximal oxygen consumption and pulmonary dimensions in small mammals. Respir. Physiol., 34: 29-44.

17. Morris P. A., 1968: Apparent hypothermia in the wood mouse (Apodemus sylvaticus). J. Zool., 155: 235-236. London.

18. Pasquis P., Lacaisse A. \& Dejours P., 1970: Maximal oxygen uptake in four species of small mammals. Resp. Physiol., 9: 298-309.

19. Puchalski W., Böckler H. \& Heldmaier G., 1983: Effect of food deprivation on thermogenic capacity in the Djungarian dwarf hamster Phodopus sungorus. J. Therm. Biol., 8: 99-101.

20. Rosenmann M. \& Morrison P., 1974: Maximum oxygen consumption and heat loss facilitation in small homoetherms by $\mathrm{He}-\mathrm{O}_{2}$. Am. J. Physiol., 226: 490-495.

21. Rosenmann M., Morrison P. \& Feist D., 1975: Seasonal changes in the metabolic capacity of red-backed voles. Physiol. Zool., 48: 303-310.

22. Sawicka-Kapusta K., 1968: Annual fat cycle of field mice Apodemus flavicollis (Melchior, 1834). Acta theriol., 13: 329-339.

23. Scelza J. \& Knoll J., 1979: The effect of acclimatization on body weight and oxygen consumption in Dipodomys panamintinus. Comp. Biochem. Physiol., 65 A: $77-84$.

24. Wang L. C. H., 1978: Factors limiting maximum cold-induced heat production. Life Sciences, 23: 2089-2098.

25. Wang L. C. H., 1980: Modulation of maximum thermogenesis by feeding in the white rat. J. Appl. Physiol., 49: 975-978.

26. Walton J. B. \& Andrews J. F., 1981: Torpor induced by food deprivation in the wood mouse Apodemus sylvaticus. J. Zool., 194: 260-263. London.

27. Wickler S. J., 1980: Maximal thermogenic capacity and body temperatures of white-footed mice (Peromyscus) in summer and winter. Physiol. Zaol., 53: $338-346$.

28. Zar J. H., 1974: Biostatistical analysis, Prentice-Hall International, Inc.: 1-620. London.

Accepted, November 26, 1984. 
Teresa CYGAN

SEZONOWE ZMIANY TERMOREGULACJI I METABOLIZMU MAKSYMALNEGO
U MYSZY WIELKOOKIEJ LESNEJ

Streszczenie

Myszy leśne wielkookie, Apodemus flavicollis (Melchior, 1834) hodowane w warunkach naturalnych zmian temperatury i fotoperiodu podlegały sezonowej aklimatyzacji. Wystąpiły $u$ nich zmiany $w$ poziomie metabolizmu maksymalnego, który w lecie wynosił 11.6 , a w zimie $13.4 \mathrm{ccm} \mathrm{O}_{2} \times \mathrm{g}^{-1} \times \mathrm{hr}^{-1}$, czyli maksymalna termogeneza była wyższa o $16 \%$. Maksymalny metabolizm wywołany niskimi temperaturami w lecie, w mieszaninie helowo-tlenowej, nastapil w temperaturze $10^{\circ} \mathrm{C}$ (która odpowiada temperaturze powietrza $-20^{\circ} \mathrm{C}$ ) - Fig. $2 \mathrm{~A}$, a w zimie $\mathrm{w}$ temperaturze $5^{\circ} \mathrm{C}\left(-30^{\circ} \mathrm{C}\right.$ w powietrzu) - Fig. 2B. Przebieg krzywych termoregulacji w powietrzu, w obu badanych sezonach, był podobny (Fig. 3A i 3B), co oznacza, że zwierzęta nie zmieniały w ciągu roku przewodnictwa cieplnego i izolacji ciała. $B M R$ nie podlegał zmianie sezonowej, gdyż w lecie wynosił 2.9 , a w zimie $3.0 \mathrm{ccm}$ $\mathrm{O}_{2} \times \mathrm{g}^{-1} \times \mathrm{hr}^{-1}$. W miesiącach zimowych myszy zdolne były podnieść metabolizm 4.5 raza, a latem 4-krotnie ponad BMR. Samce były z reguły cięższe od samic. Latem myszy osiągały średni ciężar ciała 25.9, a w zimie zwiększały go do $31.1 \mathrm{~g}$. Srednia zimowa temperatura rektalna wynosiła $37.2^{\circ} \mathrm{C}$. U dwóch osobników wystąpił spontaniczny spadek temperatury poniżej tej wartości, do 31.5 i $34.2^{\circ} \mathrm{C}$. Podczas doświadczeń prowadzonych $\mathrm{w}$ mieszaninie $\mathrm{He}+\mathrm{O} z$ zwierzęta obniżały temperaturę ciała (zanotowano spadek temperatury ciała aż o $24^{\circ} \mathrm{C}$ ) - Fig. 1. Głęboka hipotermia nie była dla myszy letalna. Po przeniesieniu zwierząt do wyższej temperatury powracały do początkowej kondycji. 